\title{
Peradaban dan Pemikiran Islam pada Masa Turki Utsmani
}

\author{
Rahmida Putri¹, Haidar Putra Daulay², Zaini Dahlan ${ }^{3}$ \\ 1,2,3 Universitas Islam Negeri Sumatera Utara Medan \\ E-mail: rahmidahputri06@gmail.com ${ }^{1}$ haidarputradaulay@uinsu.com², \\ zainidahlan@uinsu.ac.id ${ }^{3}$
}

\begin{abstract}
This paper aims to uncover and review Islamic civilization and thought during the Ottoman period. The typeof this research is using a qualitative descriptive approach, namely the author describes what is contained in the history civilization and Islamic thought during the Ottoman Turkey, as well as the progress they have made by referring to or utilizing various natural methods. The type of research used is literature review. Researchers only utilizelibrary resources by carrying out reading, processing, and recording research materials. Only collect a few book references needed in research without going into the field. The results of this study are (1) there are several civilizations, namely the field of architectural art, the field of literature and prose, and one in the field of thought, namely wahdatul manifestation pioneered by Ibn 'Arabi, (2) the progress and decline of the Ottoman Turkey.
\end{abstract}

Keywords: Civilization, Islamic Thought, Ottoman Turkey.

\begin{abstract}
Abstrak
Tulisan ini bertujuan untuk menguak dan mengulas Peradaban dan Pemikiran Islam Pada Masa Turki Utsmani. Adapun jenis penelitian ini ialah menggunakan pendekatan deskriptif kualitatif yaitu penulis memaparkan apa saja yang terdapat dalam sejarah peradaban dan pemikiran Turki Utsmani, demikian juga kemajuankemajuan yang mereka peroleh dengan merujuk atau memanfaatkan berbagai metode alamiah. Jenis penelitian yang digunakan adalah kepustakaan (library research) sebab merupakan kajian literatur. Peneliti hanya memanfaatkan sumber pustaka dengan melakukan kegiatan membaca, mengolah, dan mencatat bahan penelitian. Hanya mengumpulkan beberapa rujukan buku yang diperlukan dalam penelitian, tanpa terjun ke lapangan. Hasil Penelitian ini ialah (1)Terdapat beberapa peradaban yaitu bidang politik, Ilmu Pengetahuan, Bidang Tasawuf, Bidang Ekonomi, Bidang Sosial, Bidang Politik, Bidang Seni Arsitektur, Bidang
\end{abstract}




\begin{abstract}
Sastradan Prosa, dan satu di bidang pemikiran yaitu pemikiran wahdatul Wujud yang dipelopori oleh Ibnu 'Arabi, (2) Kemajuan dan kemunduran Turki Utsmani.
\end{abstract}

Kata Kunci : Peradaban, Pemikiran Islam, Turki Utsmani

\title{
PENDAHULUAN
}

Pada priode Umayyah dan Abbasiyyah termasuk kategori zaman yang gemilang sepanjang sejarah Islam, seusai hancurnya kota Baghdad bertepatan tahun $1258 \mathrm{M}$. sebab hal ini runtuh dan pakum peradaban Islam, priode ini juga merupakan zaman yang sangat memilukan bagi Umat Islam. Akan tetapi, peradaban Islam mulai nampak dengan munculnya tiga kerajaan besar, yang pada mulanya diketahui adanya sebuah kerajaan yang bernama Turki Utsmani, Syafawi, demikian juga Mughal.

Puncak keemasan Turki Utsmani ialah pada priode pemerintahan Sulaiman Al-Qanuni. Dengan kejayaan yang diperoleh Turki Utsmani mendapat sebutan sebagai negara terkuat di dunia hal ini terjadi sekitar abad ke16 dan 17. Hanya saja Turki Utsmani abad ke-18 sampai 19 mengalami kemunduram bertepan masa itu Konstantinopel sebagai pusat ibu Kota. Kemunduran itu menjadi tombak yang berujung masuknya rezim politik baru di Turki, pun penataan Balkan dan Timur Tengah yang baru.

Turki Utsmani termasuk kerajaan yang paling lama dan panjang perjalanannya selaras dengan sejarah yang termaktub dalam sebuah buku-buku sejarah selama 625 tahun. Dengan lamanya masa kerajaan,maka dalam kerajaan ini terdapat beberapa penguasa yang gaya kepemimpinannya bercorak ragam begitu juga dengan kemajuan peradaban yang telah sukses diraih. Kerajaan Turki utsmani itu namanya dinisbahkan kepada nenek moyang mereka yakni Sultan Utsmani ibn Sauji ibn Ertoghrol ibn Sulaiman Syah ibn Kia Alp. Kepala kabilah Kab di Asia tengah.

Mengetahui tentang sejarah sangat urgen, sebab dari sejarah banyak i'tibar atau pelajaran yang dapat diambil terkhusus dalam bidang pendidikan. Terkait dengan sejarah tersebut, penulis ingin mencoba menguak data-data yang berkenaan dengan sejarah Islam, dalam hal ini yang penulis fokuskan berkenaan dengan peradaban meliputi aspek ekonomi, politik, ilmu pengetahuan, keagamaan, seni dan arsitektur dan lain sebagainya, begitu juga 
pemikiran Islam serta perkembangannya hingga kemunduran Kerajaan Turki Utsmani.

\section{METODE PENELITIAN}

Jenis penelitian yang digunakan adalah kepustakaan (library research) sebab merupakan kajian literatur dengan mengkaji buku-buku sejarah yang berkaitan dengan penelitian. Penelitian kepustakaan ialah suatu kegiatan yang berhubungan dengan pengumpulan data pustaka penelitian yang memanfaatkan sumber pustaka untuk mendapatkan data penelitian, dengan melakukan kegiatan membaca, mengolah, dan mencatat bahan penelitian. (Mestika Zed, 2008, p.2). Yang mana jenis penelitian kepustakaan ini tidak perlu melakukan riset untuk terjun langsung ke lapangan, hanya mengumpulkan beberapa rujukan buku yang diperlukan dalam penelitian. Penelitian ini menggunakan pendekatan deskriptif kualitatif. Deskriptif Kualitatif adalah suatu penelitian, tentang peristiwa apa saja yang dialami sabyek penelitian contohnya, sikap atau perbuatannya, motivasi dan lain sebagainya dimana ia memaparkannya berupa kata-kata yang jelas dan bahasa yang mudah dipahami dengan merujuk atau memanfaatkan berbagai metode alamiah (Lexy J. Moleong, 2007, p.6).

\section{HASIL DAN PEMBAHASAN}

\section{Munculnya Kerajaan Turki Usmani}

Kurun waktu abad ke-15 (abad ke-9 H), orang Turki Ustmani membuat debut di panggung sejarah.Bangsa Turki yang menjadi pencetus berdirinya kerajaan ini yaitu berasal dari kabilah Oghuz yang berdomisiili di Mongol dan sebelah utara negeri Cina (Badri Yatim, 2001, p. 129). Sepanjang waktu 3 abad, mereka hijrah ke Turkistan, Persia demikian juga Irak. Ketika itu yang memimpin ialah Ertoghrol, mereka berkhidmah kepada Sultan Alauddin II (sultan Seljuk) pada saat itu lagi melawan Byzantium. Sultan Alauddin meraih kemenangan atas bantuan mereka. Dengan demikian, Alauddin memberikan sebuah hibah sebab mengenang jasa yang mereka berikan yaitu berupa sebidang tanah berdampingan dengan Byzantium.

Sekitar tahun 1289 M, wafatlah Ertoghrol, tatkala hal ini Sultan Alauddin menyodorkan cucunya yang bernama Utsman sebagai pemimpin yang akan memimpin di wilayah berpapasan degan Byzantium. Masa priode Utsman 
berkuasa sekitar 1290-1326 M. Rentang waktu yang tidak begitu singkat, Sultan memperhatikan pemerintah lagi masa tidak ada yang berkuasa, tereskspos peluang bagi Utsman sehingga menghantarkan martabat yang levelnya paling tinggi. Bersamaan demikian ini, majunya Utsman sebagai pemimpin, pemerintahan Seljuk pun bubar dan digantikan dengan kerajaan Utsmani dibawah kekuasaan Utsman memiliki gelar Padisyah al-Utsman (raja besar keluarga utsman).

Turki Utsmani termasuk kerajaan yang paling lama dan panjang masa kepemimpinan Kerajaan. Turki utsmani itu namanya dinisbahkan kepada nenek moyang mereka yakni Sultan Utsmani ibn Sauji ibn Ertoghrol ibn Sulaiman Syah ibn Kia Alp. Kepala kabilah Kab di Asia tengah (Sulomo, 1995, p.24).

\section{Sultan Turki Utsmani}

Turki Utsmani sekitar 625 tahun (1299-1924 M). Tidak kurang dari 38-40 Sultan yang memerintah dikerajaan tersebut. Dalam makalah ini yang tercantum hanya yang berpangaruh meliputi:
a. Sultan Utsman (699-726 H/1294-1326 M)
b. Sultan Urkhan $(726-761 \mathrm{H} / 1326-1359 \mathrm{M})$
c. Sultan Murad I (761-789 H/1359-1389 M)
d. Sultan Bayazid I (1389-1403 M)
e. Sultan Muhammad I (1403-1421 M)
f. Sultan Murad II (1421-1451 M)
g. Sultan Muhammad II (1451-1484 M
h. Sultan Salim I (1512-1520 M)
i. Sultan Sulaiman al-Qanuni (1520-1566 M)

\section{Aspek-Aspek Peradaban Islam Masa Dinasti Turki Utsmani}

Termaktub ada beberapa hal yang berkaitan perihal peradaban Islam pada masa Turki Utsmani mulai dari aspek sosial, politik, ekonomi, arsitektur, keagamaaan, ilmu pengetahuan dan lain sebagainya. Turki Usmani kategori pusat pemerintahan Islam, sebab merupakan khilafah Islam pada masanya paling masyhur dan paling kuat, bukan hanya itu juga termasuk juga Negara paling besar di dunia sehingga tak dapat dipungkiri kerjaan ini di beberapa priode banyak memperoleh masa keemasan. 


\section{Bidang Politik}

Pemerintahan Sulstan Sulaiman II, ekspansi wilayah terhampar luas, mulai dari daratan Eropa sampai Australia, Mesir, Afrika Utara, sampai ke Aljazair dan Asia hingga ke Persia. Selain itu, sukses mempertemukan dua kedaulatan yakni di laut untuk dipadukan dua kekuatannya, baik yang bersifar dunia maupun agamis (A. Kusdiana, 2013, p.145).

Kesultanan Muhammad II namanya yang populer yaitu al-Fatih, setelah meraih dan dapat menaklukkan Konstantinopel gelar ini disematkan kepada Sultan Muhammad II tepatnya tanggal 28 Mei 1453 M. Berhasil ditaklukkan Konstatinopel, oleh sebab itu nama Konstantinopel dikorvensi menjadi Istanbul. Hal ini menjadi implikasi fisik perihal kebesaran kerajaan Utsmani (Ottoman Empire). Para Tentara dengan hal demikian ini secara gamblang mudah untuk melakukan perluasan wilayah seperti Serbia, Albania dan Hongariah.

Pemerintahan Sultan Sulaiman al-Qanuni kawasan kekuasaan kerajaan Usmani terdapat tiga benua meliputi, Benua Afrika meliputi Mesir, Libia, Tunis serta Aljazair, benua Asia, meliputi Asia Kecil, Armenia, Irak, Suria, Hijaz serta Yaman. dan benua Eropa meliputi Bulgaria, Yunani, Yugoslaia, Albania, Hongaria dan Rumania (Nofrianti, \& Muslim 2019).

Priode Sultan Orkhan, beliau mentranfer tentara perang ke Byzantium akhirnya bisa menaklukkan Azmir (Smima) tahun 1327 M, Thawasyanli (1330 M), Iskandar (1338 M), Ankara (1354 M),dan Gallipoli (1356 M). Zona ini adalah bagian benua Eropa yang mula-mula kerajaan Utsmani menjadi penguasa. Selanjutnya, membuat pasukan tentara bernama Yenissari yang terhimpun dan bersatu padu antara bangsa Turki dan yang bukan Turki. Kemudian, selain Yenissari, ada pula tentara Foedal yang disebut militer taujiah yang posisinya berada dipemerintahan Pusat (A. Syalabi, 1998, p.23). Pasukan militer yang hebat dengan ciri khas santun dan taat terhadap peraturan berhasil mendapatkan kekuasaan yang sungguh luas yaitu terhampat darixAsia, Afrika dan Eropa.

\section{Bidang Ilmu Pengetahuan}

Jika ditinjau dari aspek keagamaan pemerintah sangat terselubung selaras dengan Syaria'at Islam. Ulama memiliki diktatorial disisi pemerintahan demikian juga para masyarakat. Ulama berkedudukan sebagai Mufti sehingga ada diktatorial untuk memberikan fatwa dan apa saja yang terjadi permasalahan 
terkait keagaamaan pada zaman itu (H. Bakry, 1990, p.326). Kitab-kitab yang ditulis Ulama, karya ilmiah dan semacamnya pada khilafah turki Utsmani tidak ada perkembangan, paraUlama saat itu produktif menulis syarah dan hasyiyah, lai halnya pada Abbasiyyah. Literatur-literatur khusus ilmu agama seperti tafsir, ilmu kalam, fikih, hadis stagnan.

Para khilafah ustmani lebih condong untuk tetap taqlid dan fanatik kepada satu mazhab dan kontradiksi terhadap mazhab yang lain (Badri Yatim, 2001, p. 324). Sulaiman al-Qanuni dalam masajabatannya, setiap rakyat beragama islam ditekankan wajib sholat lima kali dan berpuasa di bulan Ramadhan. Jika ada yang melanggar tidak hanya dikenai denda namun juga sanksi badan. Inilah yang membuat Sultan Sulaiman menjadi tenar di kawasan Turki Usmani, bukan hanya itu saja yang menjadikan beliau tenar yaitu karena merupakan khalifah berbudi pekerti yang baik, mampu menerjemahkan Alquran kedalam bahasa Turki, berawal dari sini nama beliau masyhur sebagai kepala negara yang paling tenar di jajaran dunia. Sultan Abdul Hamid II misalnya sangat panatik terhadap aliran Asy'ariyah sehingga memerintahkan kepada salah seorang ulama untuk menulis kitab yang berjudul al-Hushun al-Hamidiyah (Benteng Pertahanan Abdul Hamid). Beliau bersihkeras mempertahankan aliran asy'ariyah untuk membentengi rakyatnya dari paham yang menyeleneh.

Kitab tidak terhingga banyaknya di perpustakaan masa kemajuan Islam mencakup seluruh negara notabene Islam, tidak dapat dipungkiri baik bersifat umum maupun khusus. Rata-rata semua Masjid dan madrasah-madrasah terdapat sebuah perpustakaan beraneka ragam keilmuan apalagi ilmu-ilmu agama dan bahasa arab. Akan tetapi saat kemunduran pendidikan minim sekali diperdapati eksistensi perpustakaan. Adapun negara yang ada pepustakaan di Istanbul, di Mesir minim, Damsyikh, Halab, Qudus.

Pada masa Turki Utsmani, masa kemunduran pendidikan dan pengajaran Islam, perpustakaan sangat berkurang, hanya terdapat di Istambul dan sedikit di Mesir, Damsyik, Halab, Qudus. Pepustakaan berkisar 26 perpustakaan di Istambul 4 perpustakaan di penjuru lain. Jumlah kitab dalam perpustakaan itu berkisar 30.000 kitab.

\section{Bidang Tasawuf}

Al-Bektasyi dan Al-Maulawymerupakan jenis tarekat paling besarketimbang tarekat lain yang masih eksis dan perkembangannya secara drastis cepat. Tarekah Al-Bektasyi memberikan efek positif kepada 
tentara Yenissari. Sementara Tarekat Al-Maulawy memberikan efek positif kepada para raja. Seluruh madrasah bercorak nuansa sufistik untuk diproduksi menjadi zawiyah-zawiyah dengan jalan riyadhah, untuk bertakwa kepada Allah melalului seorang pengajar yang disebut dengan mursyid. Bahkan kurikulum juga, buku yang dipakai rata-rata bernuansa sufi. Kemudian, sistem riyadhah mulai nampak perkembangannya untuk memudahkan memandu para jamaah, hal inilah yang dimaksud dengan tarekat.

Adapun Ulama-Ulama yang terkenal pada Masa Turki Utsmani yaitu:

\begin{tabular}{|c|c|c|c|}
\hline No & Nama Ulama & Wafat Tahun & Karya \\
\hline 1 & $\begin{array}{l}\text { Syekh Hasan bin } \\
\text { Ahmaf al-Syabi'i } \\
\text { Mal- } \\
\text { Madabhy) }\end{array}$ & $1179 \mathrm{H} / 1756 \mathrm{M}$ & $\begin{array}{l}\text { Khasyiah al-Jam'ul dan } \\
\text { Syarah al-Jurmiyyah }\end{array}$ \\
\hline 2 & Syamsuddin Ramali & $1004 \mathrm{H} / 1595 \mathrm{M}$ & Nihayah \\
\hline 3 & Ibnu Hajar al-Haitamy & $975 \mathrm{H} / 1567 \mathrm{M}$ & Tuhfah \\
\hline 4 & $\begin{array}{l}\text { Muhammad Abdur } \\
\text { Razaq, Muhammad } \\
\text { Murtadha al-Husaini } \\
\text { al-Zabidi }\end{array}$ & $1202 \mathrm{H} / 1787 \mathrm{M}$ & $\begin{array}{l}\text { Sejarah al-Qamus } \\
\text { bernama tajjul Urusy }\end{array}$ \\
\hline 5 & $\begin{array}{l}\text { Syekh } \quad \text { Hasan al- } \\
\text { Kafrawy al-Safiy al- } \\
\text { Azhary }\end{array}$ & $1202 \mathrm{H} / 1787 \mathrm{M}$ & $\begin{array}{l}\text { Syarah-syarah } \\
\text { dan Khoisiroh-khoisiroh }\end{array}$ \\
\hline 6 & $\begin{array}{l}\text { Syekh Muhammad bin } \\
\text { Ahmad bin Arfah al- } \\
\text { Dusuqy al-Maliki }\end{array}$ & $1230 \mathrm{H} / 1814 \mathrm{M}$ & $\begin{array}{ll}\text { Ahli } & \text { Filsafat dan } \\
\text { Ilmu Falak } & \text { serta Ilmu } \\
\text { Ukur } & \end{array}$ \\
\hline 7 & Syekh Hasan al-Attar & $1250 \mathrm{H} / 1834 \mathrm{M}$ & $\begin{array}{l}\text { Ahli Ilmu Pasti } \\
\text { Kedokteran }\end{array}$ \\
\hline
\end{tabular}

\section{Bidang Ekonomi}

Turki Utsmani sukses dalam memperluas kekuasaan, pembenahan politik secara teratur, berimpilikasi pada sosial kemajuan ekonomi negara.

Para pedagang berdatangan dari berbagai penjuru baik dari dalam maupu luar negeri, wilayah Turki pada saat itu disematkan pusat perdagangan dunia. 
Selain dari pendapatan perdagangan, Turki Utsmani memiliki sumber keuangan negara yang sangat besar yaitu dari harta rampasan perang, serta negara-negara yang dapat ditaklukkan, dan orang-orang zimmi.

Turki Utsmani sebagai instruktur perdagangan, pemungut pajak (cukai) pelabuhan sebagai sumber perekonomian cukup besar bagi Turki.

\section{Bidang Sosial}

Kerajaan Turki Utsmani adalah tersusun yaitu kebudayaan persia, Arab, dan Byzantium. Persis halnya kebudayaan persia mereka mengambil perihal ajaran agama mengenai etika dan tata krama dalam kehidupan di istana. Dan Bizantyum mereka mengambilorganisasi kemiliteran dan pemerintahan. Mereka mengadopsi perihal prinsip-prinsip ekonomi, sosial, keilmuan dan huruf (Ajid Tohir, 2009, p. 186) melalui bangsa Arab. Masyarakat Turki Utsmani tenar dengan kepiawaiannya di bidang perang, yang paling diprioritaskan di bidang militer dan pertahanan.

\section{Bidang Seni Arsitektur}

Pada masa pemerintahan Sultan Sulaiman, dibangun berbagai sarana ibadah, pendidikan, kesehatan, ekonomi dan hiburan di berbagai kota besar maupun kecil. Bahkan dikatakan bahwa tidak kurang dari 235 buah bangunan hanya dikordinir oleh satu orang Arsitek asal Anatolia yang bernama Sinan. Ini membuktikan bahwa betapa tingginya kemajuan arsitektur yang dicapai Turki Usmani pada saat itu dan kemudian mempengaruhi arsitektur-arsitektur dunia Islam. Turki Utsmani banyak meninggalkan karya-karya agung berupa bangunan yang indah seperti Mesjid Jami' Muhammad al-Fatih, Mesjid Agung Sulaiman dan Mesjid Abu Ayyub al-Anshari, dan mesjid yang dulunya gereja Aya shopia. Masjid tersebut dihiasi dengan kaligrafi oleh Musa Azam (Lapudus, p. 499). Pada masa Sulaiman, di kota-kota besar lainnya banyak dibangun masjid, sekolah, rumah sakit, gedung makam,jembatan, saluran air, villa, dan pemandian umum.

\section{Bidang Sains dan Teknologi}

Adapun dalam bidang sains seperti matematika dan kedokteran. Sedangkan bidang teknologi yaitu astronomi, Taqi al-Din pada membangun observatorium tahun 1577, ia melakukan pengamatan astronomi disana sampai 
tahun 1508. Ia menghitung eksentrisitas orbit Matahari dan pergerakan tahun Apoge. Percetakan istambul pada tahun 1727 M. Sehingga akses buku-buku tentang ilmu kedokteran, ilmu kalam, ilmu pasti, sejarah, hadis,fikih dan tafsir mudah didapatkan (A.S Sulaiman, 1989, p. 45). Pada 1717 M berdiri lembaga terjemah untuk menerjemahkan ke dalam bahasa Turki buku-buku dalam berbagai bidang ilmu pengetahuan. Pada tahun 1660, cendikiawan Utsmaniah Ibrahim Efendi al-Zgetvari Tezkireci menerjemahkan karya Astronom Noel Duret yang ditulis tahun 1637 ke bahasa arab. Seorang penulis atlas bedah yang mula-mula produktif ensiklopedia kedokteran besar terakhir dari dunia Islam bernama Serafeddin Sabuncuaglu.

\section{Bidang Sastra dan Prosa}

Bidang Sastra dan Prosa kerajaan Utsmani melahirkan dua tokoh terkemuka yaitu Katip Celebi dan Elvya Celebi. Katip Celebi yang masyhur dikenal dengan sebutan Musthafa Abdullah seorang penulis terbesar (saat, 2011). Adapun karyanya yang besar ialah Kasyf al-Zunun Fi Asma'i al-Kutub Wa alFunun, sebuah presentasi biografi penulis-penulis penting di dunia timur bersama daftar dan deskripsi lebih dari 1.500 buah buku berbahasa Turki, Persia, dan Arab (Samsu Munir, 2009, p. 203).

\section{Bidang Pemikiran}

Ibnu 'Arabi, dalam sejarah pemikiran Islam Ibnu 'Arabi dikenal sebagai tokoh produktif. Salah satu teori dan pendapatnya yang masyhur ialah wahdatul wujud maksuknya ialah Allah pada setiap sesuatu dan sebenarnya ialah setiap sesuatu itu.

\section{Turki Usmani dan Peranannya dalam Peradaban islam}

Pengaruh peradaban Islam sangat berfek terhadap Turki Utsmani jika ditinjau dari aspek militer. Segi militer Turki Utsmani masyhur dan peringkat tertinggi dengan bala tentara yang kuat dan tak gentar. Demikian membuat Peradaban Islam masa Turki Usmani membuming ketenarannya, bahkan kerajaan ini mempunyai ciri khas tersendiri sampai abad ke-13 bahasa arab menjadi bahasa legal, walaupun secara keseluruhan Turki tidak mengikuti jejak peradaban Arab. 
Bersamaan dengan pernyataan di atas bahwa peran Turki Usmani relevan dan berpengaruh terhadap majunya perkembangan peradaban Islam. Luasnya kawasan kekuasaan terhampar mulai Asia sampai Eropa jangka waktu selama 625 tahun, sebab ini interaksi peradaban dengan penjuru wilayah di bawah kekuasaan Turki dan satu sama lain saling mempengaruhi, hingga timbul kesatuan peradaban menjadi kokoh. Nyatanya, masa abad 21 ini, seperti yang dinyatakan Reuters, Turki masih menjelajahi keterbelakangannya terutama dalam pendidikan.

\section{Kemajuan yang Telah Dicapai oleh Kerajaan Turki Usmani}

Seusai Sultan Sulaiman wafat, peristiswa perebutan kekuasaan antara puteranya-puteranya dan menyebabkan kemunduran. Walaupun begitu, Kemajuan yang diperoleh Turki Utsmani di beberapa aspek peradaban, meliputi:

\section{Bidang Militer dan Pemerintahan}

Para tentara dapat mengatur dan menata sehingga negara Utsmani dijuluki mesin perang terkokoh dan paling superior, kemudian menyampaikan motivasi yang dapat mempengaruhi tentara dalam merebut kekuasaan negeri non muslim (Fatah Syukur, 2015, p.138). Elemen garda pertama yang mendorong kemajuan ini ialah tabiat bangsa Turki itu sendiri yang ada ciri khas kemiliteran, disiplin, dan patuh terhadap peraturan. Penataan antusiasme militer kerajaan diorganisasi bagus dan terorganisir sejak pemerintahan Sultan Murad I. Tarap berikutnya Orkhan membuat reformasi dalam tubuh organisasi militer dengan model pergeseran personil pimpinan dan reformasi dalam keanggotaan. Penduduk non Turki digolongkan sebagai anggota. Program ini berhasil dijalankan dengan terwujudnya kelompok militer baru yakni Jenissari dan Inkisyariyah.

\section{Bidang Ilmu Pengetahuan dan Budaya}

Turki Utsmani sangat maju pada bidang kemiliteran, sementara dalam ilmu pengetahuan mereka tidak nampak unggul. Hanya saja, mereka terus beraksi dalam arsitektur yangindah seumpama masjid jami' Sulthan Muhammad al-Fatih. Kebudayaan Turki Utsmani ialah kombinasi beraneka ragam kebudayaan termasuk kebudayaan Persia. 


\section{Bidang Keagamaan}

Jika ditinjau dari aspek keagamaan pemerintah sangat terselubung selaras dengan Syaria'at Islam. Ulama memiliki diktatorial disisi pemerintahan demikian juga para masyarakat. Ulama berkedudukan sebagai Mufti sehingga ada diktatorialuntuk memberikan fatwa.

\section{Mundurnya Kerajaan Turki Utsmani}

Kekuasaan Turki Utsmani drastis mundur, fatah semangat, dan terus dihiasi dengan kegemilangan dan merasa ada kelebihan sehbabis tentara diri banyak kelebihan setalah tentara yang sanggup mampu memperbanyak kekuasaan, sanggup menentramkan perbatasan, melembutkan musuh, dan mempertahankan kedudukan. Model hidup demikian ini seolah-seolah zat asam yang menikam akhirnya membawa kesengsaraan pada rakyat dan negara.

Setelah wafatnya Sulthan Sulaiman al-Qanuni (1566 M), Kerajaan Turki Utsmani mulai memasuki zona kehancuran secara perlahan-perlahan. Sultan Sulaiman al-Qanuni diganti oleh Salim II (1566-1573 M). Peristiwa peperangan oleh Armada laut kerajaan Turki Usmani melawan Armada laut keristen, mereka berasal dari angkatan laut Spanyol, peristiwa ini berada di Selat Laut Uponto, Yunani. Turki Usmani memperoleh kekalahan pada peperangan ini. Wilayah Tunisia dapat dirampas kembali dibawah pemerintahan Sulthan Murad III (1575 M) . Hal-hal yang menunjang kemunduran Turki, meliputi: 1) Ekspansi daerah kekuasaan Utsmani. Khilafah Turki hanya menaati ambisius penaklukkan, sedangkan sistematikan dan tata pemerintahan diabaikan. Manakala imperium Utsmani dibelenggu kelemahan, daerah-daerah perbatasan dari pusat jarak tempuhnya cukup jauh, secara gamblang dikuasai oleh lawan. 2) Pemborontakan Yennisary. Pada masa gkegentingan Yennisary tidak mengaplikasikan komitmen dengan cara mpenyaringan dan prestasi, akan tetapi eksistensinya lebih dominan dari keturunan dan kabilah tertentu. Tokohtokoh Yennisary terselubung pertikaian kepada para penguasa sampai pertikaian menjadi-jadi beberapa kali yaakni pada tahun 1525, 1632, 1727, dan 1826. 3) Raja yang tidak sigap. Peneruspenguasa Utsmani se usai Sulaiman al-Qanuni cecodong tidak berdaya dalam melawan musuh. Mereka rakus terhadap pangkat dan kedududkan, bahkan saling bertumpah darah. Kehidupan di kerjaah dalam kemewahan. 4) Minimnya pemasukan negara 
faktor sejumlah peperangan, terkait sebagian peperangan pihak Turki memperoleh kekalahan. Banyak wilayah-wilayah kekuasaan Utsmani direbut oleh lawan sehingga menyokong minimnya pendapatan negara. Sedangkan pengeluaran negara masih banyak baikbiaya militer dan biaya perang . Hal ini yang menjadi faktor secara perlahan perekonomian berpengaruh pertahanan militer Utsmani. 5) Stagnan bidang ilmu pengetahuan danxteknologi. Padahal masa bangsa Eropa sanggup memajukan teknologi persenjataan. Tat kala pertempuran dimedan perang, pihak Utsmani terus menerus memperoleh kekalahan. 6) Munculnya gerakan nasionalisme. Persfektif ini mulai menampakkan kesadaran negara dengan beragam faktor atas beberapa wilayah yang didudukinya awalnya dari gerakan agresi dan menundukkan. Walaupun penguasa Turki sudah melakukan semaksimal mimpin selama memimpin Turki, akan tetapi keberadaan penguasa Utsmani masih dilihat seperti orang asing. Gerakan kebangsaan ini tbukan hanya di wilayah-wilayah Barat, berkembang, tetapi meraja lela di wilayahwilayah Timur. Konsekuensinya satu ranah kekuasaan Utsmani lepas satu persatu (Fatah Syukur, 2015, p. 151-152). 


\section{KESIMPULAN}

Puncak keemasan Turki Utsmani ialah pada priode pemerintahan Sulaiman Al-Qanuni. Dengan kejayaan yang diperoleh Turki Utsmani mendapat sebutan sebagai negara terkuat di dunia hal ini terjadi sekitar abad ke16 dan 17. Hanya saja Turki Utsmani abad ke-18 sampai 19 mengalami kemunduram bertepan masa itu Konstantinopel sebagai pusat ibu Kota. Kemunduran itu menjadi tombak yang berujung masuknya rezim politik baru di Turki, pun penataan Balkan dan Timur Tengah yang baru.

Termaktub ada beberapa hal yang berkaitan perihal peradaban Islam pada masa Turki Utsmani mulai dari aspek sosial, politik, ekonomi, arsitektur, keagamaaan, ilmu pengetahuan dan lain sebagainya. Turki Usmani kategori pusat pemerintahan Islam, sebab merupakan khilafah Islam pada masanya paling masyhur dan paling kuat, bukan hanya itu juga termasuk juga Negara paling besar di dunia sehingga tak dapat dipungkiri kerjaan ini di beberapa priode banyak memperoleh masa keemasan.

Diantara kemunduran Turki Utsmani Munculnya gerakan nasionalisme. Persfektif ini mulai menampakkan kesadaran negara dengan beragam faktor atas beberapa wilayah yang didudukinya awalnya dari gerakan agresi dan menundukkan. Walaupun penguasa Turki sudah melakukan semaksimal mimpin selama memimpin Turki, akan tetapi keberadaan penguasa Utsmani masih dilihat seperti orang asing. Gerakan kebangsaan ini tbukan hanya di wilayah-wilayah Barat, berkembang, tetapi meraja lela di wilayahwilayah Timur. Konsekuensinya satu ranah kekuasaan Utsmani lepas satu persatu. 


\section{DAFTAR PUSTAKA}

Amin, Samsu Munir. (2009). “Sejarah Peradaban Islam”. Amzah.

Bakry, H. (1990). Pedoman Islam di Indonesia. Cet. V. UI Press.

Kusdiana, A. (2013). "Sejarah dan Kebudayaan Islam Periode Pertengahan". CV. Pustaka Setia.

Munir Amin, Samsu. (2009). “Sejarah Peradaban Islam”, cet. ke-1, Jakarta: Amzah

Nasution, Harun. (1996). "Pembaharuan dalam Islam". Bulan Bintang.

Nata, Abuddin, (2010) Sejarah Pendidikan Islam, cet. ke-2; Jakarta: PT. Raja Grapindo Persada.

Nofrianti, M., Muslim, K.L. (2019). Kemajuan Islam pada Masa Kekaisaran Turki Utsmani. Jurnal Fuaduna : Jurnal Kajian Keagamaan dan Kemasyarakatan. V. 3 No. 1 Juni 2019 (22-32) https://ejournal.iainbukittinggi.ac.id/index.php/fuaduna/article/view/13 31

Saat, S. (2011). "Pendidikan Islam di Kerajaan Turki Usmani". Hunafa: Jurnal Studia Islamika. V. 8, No. 1 Juni 2011 (138-152) https://jurnalhunafa.org/index.php/hunafa/article/view/91

Sulaiman, A. S. (1989). "Tarikh at-Turki Fi Asia al-Wustha Ajib Thahir Perkembangan Peradaban di Kawasan Dunia Islam: Melacak Akar-Akar Sejarah, sosial, politik dan Budaya Umat Islam". Maktabah Angelo.

Sulomo. (1995). “Sejarah Kebudayaan Islam". CV.Wicaksana.

Syalabi, A. (1988). "Sejarah dan Kebudayaan Islam: Imperium Turki Usmani". Kalam Mulia.

Syukur, Fatah. (2015). “Sejarah Peradaban Islam”. PT Pustaka Rizki Putra

Syalabi, Ahmad, (1988). "Sejarah dan Kebudayaan Islam: Imperium Turki Usmani". Jakarta: Kalam Mulia,

Tohir, Ajid. (2009). Perkembangan Peradaban di Kawasan Dunia Islam. Rajawali Pers.

Yatim, Badri. (2001). "Sejarah Peradaban Islam". PT Raja Grapindo Persada. 